\title{
Bibliography
}

Many more works than listed here were consulted - mostly at the Cambridge University Library, the British Library, the Institute of Historical Research (London), the Library of Congress, and the University of Delaware. The sources listed below are those either cited in the text or particularly useful to the task of collecting data on the subject. I was also fortunate to be able to consult some unpublished material at the History of Parliament in London, and in the office of the late Professor Edith Johnston-Liik, editor of the history of the Irish Parliament, at Queen's University, Belfast.

The magazine Country Life contains over a century's worth of history relating to the British landed elite (generally of a high scholarly standard) that is frequently consulted by those interested in architecture but neglected by social and political historians.

\section{Reference Works}

The following three sources are usually not cited. Much important information has been derived from them.

DNB - Dictionary of National Biography (original edition)

ODNB - Oxford Dictionary of National Biography

VCH - Victoria County Histories

Bateman, John, The Great Landowners of Great Britain and Ireland, ed. David Spring, Leicester, 1971 $[1876,1883]$.

Bindoff, S. T., The House of Commons 1509-1558, London, 1982, 3 vols.

Burke's Landed Gentry, various editions.

Burke's Landed Gentry of Ireland, various editions.

Burke's Peerage and Baronetage, London, various editions.

Burke, John and John Bernard Burke, The Extinct and Dormant Baronetcies of England, London, 1841.

Burke, J. B., A Visitation of Seats and Arms of the Noblemen and Gentlemen of Great Britain and Ireland, sec. series, 1854.

Cockayne, G. E., The Complete Baronetage, 1900-06 [1983].

Cockayne, G. E., and Vicary Gibbs, The Complete Peerage, [1887-98] and 1910-59 and 2000, 14 vols. Dictionary of Welsh Biography, 1959.

Fisher, David, The House of Commons 1820-1832, Cambridge, 2009, 7 vols.

Hasler, P. W., The House of Commons 1558-1603, London, 1981, 3 vols.

Hayton, D. W., The House of Commons 1690-1715, Cambridge, 2002, 5 vols.

Henning, Basil Duke, The House of Commons 1660-1690, London, 1983, 3 vols.

Johnston-Liik, Edith Mary, History of Irish Parliament 1692-1800, Belfast, 2002, 6 vols.

Lists of Sheriffs for England and Wales from the Earliest Times to AD 1831, New York, 1963 [1898].

Namier, Sir Lewis and John Brooke, The House of Commons 1754-1790, London, 1964, 3 vols.

Official Return of Members of Parliament, London, 1878-79.

Paley, Ruth, ed., The House of Lords 1660-1715, Cambridge, 2016, 5 vols. 
Return of Owners of Land of One Acre and Upwards ... in Ireland, Baltimore, 1988 [1876].

Roskell, J. S., Linda Clark and Carole Rawcliffe, The House of Commons 1386-1421, Stroud, 1992, 4 vols.

Rubinstein, William D., Who Were the Rich?: A Biographical Directory of British Wealth-holders, Volume I, 1809-1839, London, 2009.

Sainty, J. C., Lists of Lieutenants of Counties 1585-1642 and 1660-1974 (IHR, London) 1970, 1979.

Sedgwick, Romney, The House of Commons 1715-1754, London, 1970, 2 vols.

Stenton, Michael and Stephen Lees, Who's Who of British Members of Parliament, 1832-1979, Hassocks, 1976-81, 4 vols.

Thrush, Andrew and John P. Ferris, The House of Commons 1604-1629, Cambridge, 2010, 6 vols.

Wedgwood, Josiah C., and A. D. Holt, History of Parliament: Biographies of Members of the Commons House 1439-1509, London, 1936, 2 vols.

Young, Margaret D., ed., The Parliaments of Scotland, Burgh and Shire Commissioners, Edinburgh, 1992, 2 vols.

\section{Lournals}

Country Life

The Irish Genealogist

\section{Online Sources}

History or Parliament, www.historyofparliamentonline.org/research/members

Timothy William Ferres, "Lord Belmont in Northern Ireland", www.lordbelmontinnorthernireland, $b$ logspot.com

Moore Institute for Research in the Humanities and Social Science, NUI Galway, "Landed Estates Database", www.landedestates.nuigalway.ie

Nick Kingsley, "Landed Families of Britain and Ireland”. www.landedfamilies.blogspot.com/

\section{Books and Articles}

Acheson, Eric, A Gentry Community: Leicestershire in the Fifteenth Century, c. 1422-1485, Cambridge, 1992.

Adams, Maxwell, "Some Notes on the Churches at the Manors of East and West Ogwell”, Report and Transactions of the Devonshire Association, xxxii, 1900, 229-48.

Anderson, James, Members of Parliament for Glasgow, Glasgow \& District: From the Union to the Reform Bill, 1928.

Angus-Butterworth, Lionel, Old Cheshire Families, Manchester, 1932.

Bardon, Jonathan, A History of Ulster, Belfast, 1992.

Batt, Elisabeth, The Moncks and Charleville House: a Wicklow Family in the Nineteenth Century, Dublin, 1979.

Beard M., Acres and Heirlooms, the Survival of Britain's Historical Estates, New York, 1989.

Beastall, T. W., A North Country Estate: the Lumleys and Saudersons as Landowners 1600-1900, London, 1975.

Beckert, Sven, Empire of Cotton: A Global History, 2014.

Beckett, J. V., The Aristocracy in England, 1660-1914, Oxford, 1986. 
Beckett, John, The Rise and Fall of the Grenvilles: Dukes of Buckingham and Chandos, 1710 to 1921, Manchester, 1994.

Beckett, J. C., The Anglo-Irish Tradition, Ithaca, 1976.

Bence-Jones, Mark, The Catholic Families, London, 1992.

Bennett, H. S., The Pastons and Their England, Cambridge, 1968.

Beresford, Philip, The Book of the British Rich, New York, 1990.

Bevan, Alfred B., The Parliamentary Representation of Lancashire, 1258-1885, London, 1889.

Blake, Tarquin, Abandoned Mansions of Ireland, Wilton, Cork, 2010-12, 2 vols.

Bourke, Eamon, Burke, Bourke, and De Burgh, Dublin, 1990.

Brown, D., "'Cotton Lord' to Landed Aristocrat: the Rise of Sir George Philips," Historical Research, Ixix, 1996, 62-82.

Brunton, D. and D. H. Pennington, Members of the Long Parliament, London, 1954.

Bunbury, T., The Landed Gentry \& Aristocracy: Kildare, Dublin, 2004.

Burns, Robert E., Irish Parliamentary Politics in the Eighteenth Century: Volume 11714-1730 and Volume 2 1730-1760, Washington, 1989 and 1990.

Burtchell, G. D., Genealogical Memoirs of the Members of Parliament for the County and City of Kilkenny, Dublin, 1888.

Cahill, Kevin, Who Owns Britain, Edinburgh, 2001.

Callander, Robin Fraser, A Pattern of Landownership in Scotland: with Particular Reference to Aberdeenshire, Finzean, 1987.

Cannadine, David, Aspects of Aristocracy: Grandeur and Decline in Modern Britain, New Haven, 1994.

Cannadine, David, The Decline and Fall of the British Aristocracy, New Haven, 1990.

Cannadine, David, Lords and Landlords: the Aristocracy and the Towns, 1774-1967, Leicester, 1980.

Cannadine, David, ed., Patricians, Power and Politics in Nineteenth-Century Towns, New York, 1982.

Cannon, John, Aristocratic Century: the Peerage of Eighteenth-century England, Cambridge, 1984.

Carpenter, Christine, Locality and Polity: a Study of Warwickshire Landed Society 1401-1499, Cambridge, 1992.

Cecil, Lord David, Some Dorset Country Houses: a Personal Selection, Stanbridge, 1988.

Chambers, Anne, Chieftain to Knight: Tibbott-ne-Long Bourke (1567-1629), Dublin, 1983.

Christie, Ian R., British 'Non-Elite’ MPs, 1715-1820, Oxford, 1995.

Christie, Ian R., Myth and Reality in Late Eighteenth Century British Politics, London, 1970.

Clarendon, Earl of, Selections from The History of the Rebellion and Civil Wars and the Life by Himself, ed., G. Huehns, Oxford, 1968.

Clark, Desmond, Arthur Dobbs, 1689-1765, Chapel Hill, 1957.

Clemenson, H. A., English Country Houses and Landed Estates, London, 1982.

Cliffe, J. T., The Yorkshire Gentry from the Reformation to the Civil War, London, 1969.

Cliffe, J. T., The World of the Country House in Seventeenth-Century England, New Haven, 1999.

Collett-White, James, Inventories of Bedfordshire Country Houses: 1714-1830, Bedford, 1995.

Colyear, R. J., “Decline of a Great Estate”, Welsh History Review, ix, 1979, 418.

Connolly, S. J., Religion, Law, and Politics: the Making of Protestant Ireland, 1660-1760, Oxford, 1992.

Cooke, Robert, West Country Houses, Bristol, 1957.

Coss, Peter, The Origins of the English Gentry, Cambridge, 2003.

Country Houses in Great Britain, New Haven, 1979

Coward, Barry, The Stanleys, Lord Stanley, and Earls of Derby, 1385-1672, Manchester, 1983.

Cragoe, M., An Anglican Aristocracy: the Moral Economy of the Landed Estates in Carmarthenshire, 1832-1895, Oxford, 1996.

Craven, Maxwell and Michael Stanley, The Derbyshire Country House, Derby, 1991. 
Cronin, Denis A., A Galway Gentleman in the Age of Improvement: Robert French of Monivea 1716-79, Dublin, 1995.

Crosleigh, Charles, Descent and Alliances of Crosleigh and Coddington and Evans, London, 1904 Dakers, Caroline, Clouds: The Biography of a Country House, New Haven, 1993.

Dashwood, Sir Francis, The Dashwoods of West Wycombe, London, 1987.

Davies, R. R., The Age of Conquest: Wales, 1063-1415, Oxford, 1992.

Delderfield, E. R., West Country Historic Houses and Their Families, Vol. 2, Newton Abbot, 1970.

Denholm-Young, N., The Country Gentry in the Fourteenth Century, Oxford, 1969.

De Vere, Joan, The Ruin Reconciled: A Memoir of Anglo-Ireland: 1913-1959, Dublin, 1990.

Dickson, John, "The Colvill Family of Ulster", Ulster Journal of Archeology, $2^{\text {nd }}$ ser., vol. 5, 139-45.

Donnelly, Eithne, "The Roches, Lords of Fermoy", Journal of the Cork Historical and Archeological Society, 1933, xxxviii, pp. 86-91 and ff.

Dunboyne, Lord, Butler Family History, $7^{\text {th }}$ ed., Dublin, 1991.

Dunning, Robert, Some Somerset Country Houses, Wimborne, 1991.

Elton, Arthur and Brett Harrison and Keith Wark, Researching the Country House: a Guide for Local Historians, London, 1992.

Emery, Anthony, Dartington Hall, Oxford, 1970.

Emery, Anthony, Greater Medieval Houses of England and Wales: 1300-1500, Volume III, Southern England, Cambridge, 2006.

English, Barbara, The Great Landowners of East Yorkshire 1530-1910, New York, 1990.

Figueirdo, Peter de and Julian Treuherz, Cheshire Country Houses, Chichester, 1998.

Finch, Mary E., The Wealth of Five Northamptonshire Families 1540-1640, Northampton, 1966.

Forman, Sheila, Scottish Country Houses and Castles, Collins, Glasgow, 1967.

Foss, Arthur, The National Trust Country House Treasures, London, 1980.

Franklin, Jill, The Gentleman's Country House and Its Plan 1835-1914, London, 1981.

Fraser, W. Hamish and R. J. Morris, People and Society in Scotland, 2 vols., Edinburgh, 1990.

Gash, Norman, Politics in the Age of Peel: A Study in the Technique of Parliamentary Representation, 1830-1850, London, 1953.

Ginter, Donald E., A Measure of Wealth: The English Land Tax in Historical Analysis, Montreal, 1992.

Girouard, Mark, "Enmore Castle” in Decantations, ed. Agnes Bernelle, Dublin, 1992, 39-46.

Girouard, Mark, The Victorian Country House, revised and enlarged edition, New Haven, 1979.

Given-Wilson, C., The English Nobility in the Late Middle Ages, London, 1987.

Gordon, Peter, The Wakes of Northamptonshire, Northampton, 1992.

Guinness, Desmond and William Ryan, Irish Houses and Castles, Thames and Hudson, London, 1973.

Gwynn, Denis, The Life of John Redmond, Freeport, NY, 1932.

Habakkuk, John, Marriage, Debt and the Estates System: English Landownership 1650-1950, Oxford, 1994.

Hancock, David, Citizens of the World: London Merchants and the Integration of the British Atlantic Community, 1735-1785, Cambridge, 1995.

Harris, B. E., ed., Victoria County History of the County of Cheshire, Oxford, 1979, ii, 102.

Harris, Paul, Life in a Scottish Country House: the Story of A. J. Balfour and Whittingehame House, Whittingehame, 1989.

Harris, R. W., Clarendon and the English Revolution, Stanford, 1983

Hawkins, Desmond ed., The Grove Diaries: The Rise and Fall of an English Family 1809-1925, Newark, 1995.

Heal, F. and C. Holmes, The Gentry in England and Wales, 1500-1700, London, 1994.

Heward, John and Robert Taylor, The Country Houses of Northamptonshire, London, 1996.

Hicks, David, Irish Country Houses: A Chronicle of Change, Wilton, Cork, 2012.

A History of Northumberland, Newcastle, 1896, vol. iii. 
Howell, David W., Patriarchs and Parasites: The Gentry of South-West Wales in the Eighteenth Century, Cardiff, 1986.

Hussey, Christopher, English Country Houses: Early Georgian 1715-1760, London, 1955.

Hussey, Christopher, English Country Houses: Late Georgian 1800-1840, London, 1955.

Hussey, Christopher, English Country Houses: Mid Georgian 1760-1800, London, 1955.

Jackson, Alvin, Colonel Edward Saunderson, Land and Loyalty in Victorian Ireland, Oxford, 1995. Jackson-Stops, Gervase, The Country House in Perspective, London, 1990.

James, Mervyn, Family, Lineage, and Civil Society: a Study of Society, Politics and Mentality in the Durham Region 1500-1640, Oxford, 1974.

James, Mervyn, Society, Politics and Culture: Studies in Early Modern England, Cambridge, 1986. Jenkins, Geriant, The Foundations of Modern Wales: Wales 1642-1780, Oxford, 1987.

Jenkins, P., The Making of a Ruling Class: the Glamorgan Gentry 1640-1790, Cambridge, 1983.

Johnson, Joan, The Gloucestershire Gentry, Gloucester, 1989.

Johnston, Edith Mary, Great Britain and Ireland, 1760-1800: A Study in Political Administration, Edinburgh, 1963.

Jones, Clyve, ed., A Short History of Parliament: England, Great Britain, The United Kingdom, Ireland, and Scotland, Rochester, 2009.

Jones, Francis, Historic Houses of Pembrokeshire and Their Families, Pembrokeshire, 1996.

Jones, Views of the Seats of Noblemen and Gentlemen in England, Wales, Scotland and Ireland, sec. ser., London, 1829.

Jones, Winston G., The Wynnes, Manorhamilton, Sligo, 1994.

Keeler, Mary, The Long Parliament, 1640-41: a Biographical Study of Its Members, Philadelphia, 1954.

Kennedy, Carol, Harewood: the Life and Times of an English Country House, London, 1982.

Kenworthy-Browne, John and Peter Reid, Michael Sayer, David Watkin, Burke's and Savills Guide to Country Houses: East Anglia, Volume III, London, 1971.

Kingsley, Nicholas, The Country Houses of Gloucestershire, Volume I 1500-1660, Cheltenham, 1989. Kingsley, Nicholas, The Country Houses of Gloucestershire, Volume II 1660-1830, Chichester, 1992. Kingsley, Nicholas and Michael Hill, The Country Houses of Gloucestershire, Volume III 1830-2000, Chichester, 2001.

Knight, Caroline, London's Country Houses, Chichester, 2009.

Knox, James, The Scottish Country House, London, 2012.

Ladd, Frederick J., Architects at Corsham Court, Bradford on Avon, Wilts., 1987.

A Landlord's Garden: Derreen Demesne, County Kerry, sec. ed., Bantry, 2005.

Larmine, Vivienne, Wealth, Kinship and Culture: The Seventeenth-Century Newdigates of Arbury and Their World, Boydell Press, Woodbridge, 1995

Laslet, Peter, “The Rise and Fall of an English Family” History Today, III, 1953, 535-43.

Lawrence, W. T., Parliamentary Representation of Cornwall, Truro, n.d., 34-52

Leach, Terence R., Lincolnshire Country Houses \& Their Families, Parts One and Two, Lincoln, 1990-91.

Lees-Milne, James, English Country Houses: Baroque 1685-1715, London, 1970.

Legg, Rodney, Dorset Families, Tiverton, 2002.

Lloyd, Thomas, The Lost Houses of Wales, London, 1989.

Lubenow, William, Parliamentary Politics and the Home Rule Crisis: the British House of Commons in 1886, Oxford, 1988.

Lyons, Mary Cecelia, Illustrated Incumbered Estates, Ireland, 1850-1905, Whitegate, Clare, 1993.

MacDonagh, Oliver, O'Connell: The Life of Daniel O'Connell 1775-1847, London, 1991.

Maguire, W. A., The Downshire Estates in Ireland 1801-1845, Oxford, 1972.

Malchow, H. L., Gentleman Capitalists: the Social and Political World of Victorian Businessmen, Stanford, 1992. 
Malcolmson, A. P. W., John Foster: the Politics of the Anglo-Irish Ascendancy, Oxford, 1978.

Masters, Brian, The Dukes: The Origins, Ennoblement and History of Twenty-six Families, London, 2001.

McCord, Norman, British History 1815-1906, Oxford, 1991.

McPhee, John, The Crofter and the Laird, New York, 1992.

Meisel, Janet, Barons of the Welsh Frontier 1066-1272, London, 1980

Millar, A. H., The Historical Castles \& Mansions of Scotland, London, 1890.

Mingay, G. E., English Landed Society in the Eighteenth Century, London, 1970 [1963].

Mingay, G. E., The Gentry: The Rise and Fall of a Ruling Class, London, 1976.

Mitchell, Anthony, Kingston Lacy, London, 1994.

Montgomery-Massingberd, Hugh, The Field Book of Country Houses and Their Owners: Family Seats of the British Isles, London, 1988.

Moody, T. W. and Vaughan, W. E., A New History of Ireland, IV, Eighteenth-Century Ireland 1691-1800, Oxford, 2009.

Morgan, Gerald, $A$ Welsh House and Its Family, The Vaughans of Trawsgoed, Ceredigion, 1997.

Morris, R. J., Class, Sect, and Party: The Making of he British Middle Class: Leeds 1820-1850, Manchester, 1990.

Morris, F. O., A Series of Picturesque Views of Seats of Noblemen and Gentlemen of Great Britain and Ireland, London, 1880, 7 volumes.

Moreton, C. E., The Townshends and Their World: Gentry, Law, and Land in Norfolk, c. 1450-1551, Oxford, 1992.

Mullin, T. M., Coleraine in Bygone Centuries, Belfast, 1976.

Neave, David and Edward Waterson, Lost Houses of East Yorkshire, Beverley, 1988.

Negus, Arthur, A Tour of Twelve Great Country Houses, London, 1985.

Nicolson, Harold, The Desire to Please, New York, 1943.

O’Byrne, Robert, Luggala Days, New York, 2012.

O'Connell, Maurice, Daniel O'Connell, Dublin, 1990.

Oswald, Arthur, Country Houses of Dorset, London, 1959.

Paley, Ruth and Paul Seaward, eds., Honor, Interest and Power: An Illustrated History of the House of Lords, 1660-1715, Rochester, 2010.

Parker, Matthew, The Sugar Barons, London, 2011.

Payling, Simon, Political Society in Lancastrian England: the Greater Gentry of Nottinghamshire, Oxford, 1991.

Pearman, Robert, The Cadogan Estate: A History of a Landed Family, London, 1986.

Perceval-Maxwell, M., The Scottish Migration to Ulster, London, 1973.

Pevsner, Nicklaus and David Lloyd, Hampshire and the Isle of Wight, Penguin, 1967.

Phillips, John A., The Great Reform Bill in the Boroughs: English Electoral Behavior: 1818-1841, Oxford, 1992.

Pielou, Pierce Leslie, The Leslies of Tarbert, Dublin 1935.

Plumb, J. H., Sir Robert Walpole: The Making of a Statesman, Boston, 1956.

Quiney, Anthony, Kent Houses, Woodbridge, 1993.

Rampini, Charles, A History of Moray and Nairn, Edinburgh, 1897.

Rapp, Dean, "Social Mobility in the Eighteenth Century: the Whitbreads of Bedfordshire 1720-1815", Economic History Review, 27 1974, 380-94.

Rich, Lawrence, Inherit the Land: Landowners in the 'Eighties, London, 1987.

Richards, Eric, The Leviathan of Wealth: the Sutherland Fortune in the Industrial Revolution, London, 1973.

Roberts, W. M., Lost Country Houses of Suffolk, Woodbridge, 2010.

Robinson, John Martin, The Dukes of Norfolk, Oxford, 1983. 
Robinson, John Martin, Felling the Ancient Oaks: How England Lost Its Great Country Estates, London, 2011.

Robinson, John Martin, A Guide to the Country Houses of the North-West, London, 1991.

Roebuck, Peter, ed. Macartney of Lisanoure 1737-1806, Belfast, 1983.

Roebuck, Peter, Yorkshire Baronets 1640-1760: Families, Estates and Fortunes, London, 1980.

Rosenheim, James M., The Emergence of a Ruling Order: English Landed Society, 1650-1750, London, 1997.

Rowse, A. L., The Early Churchills, New York, 1956.

Rowse, A. L., The Little Land of Cornwall, Gloucester, 1986.

Rubinstein, W. D., Men of Property: the Very Wealthy in Britain since the Industrial Revolution, London, 1981.

Rubinstein, W. D. "New Men of Wealth and the Purchase of Land in the Nineteenth-Century Britain”, Past and Present, 1981, 92, 132.

Rubinstein, W. D., “The Structure of Wealth-holding in Britain 1809-39”, Historical Research, 65, 1992, 74-89.

Russell, Una and Audey Grindrod, The Manor Houses of Dorset, Stanbridge, 2007.

Saul, Nigel, Knights and Esquires: The Gloucestershire Gentry in the Fourteenth Century, Oxford, 1981.

Sayer, Michael, The Disintegration of a Heritage: Country Houses and Their Collections 1979-1992, Norwich, 1993.

Scott, John, Who Rules Britain?, Cambridge, 1991.

Scriven, Marcus, Splendour and Squalour: The Disgrace and Disintegration of Three Aristocratic Dynasties, London, 2010.

Shirley, E. P., The Noble and Gentle Men of England, London, 1866.

Simms, J. G., David Hayton, and Gerald O’Brien, War and Politics in Ireland 1649-1730, London, 1986.

Skidmore, Warren, The Scudamores of Upton Scudamore, Akron, 1982.

Smith, R. B., Land and Politics in the England of Henry VIII: The West Riding of Yorkshire, 1530-46, Oxford, 1970.

Smythe, Colin, Guide to Coole Park Co. Galway: Home of Lady Gregory, $4^{\text {th }}$ ed., 2011.

Spring, D. and E. Spring, "Social Mobility and the English Landed Elite", Canadian Journal of History, 21 (1986), 333-51.

Spring, D. and E. Spring, “The English Landed Elite, 1540-1880”, Albion, 17 (1985) 149-80 and 393-96.

Spring, E., Law, Land, and Family: Aristocratic Inheritance in England 1300 to 1800, Chapel Hill, 1993.

Stevenson, John, Two Centuries in Life in Down 1600-1800, Belfast, 1920.

Stone, Lawrence, The Crisis of the Aristocracy 1558-1641, Oxford, 1979.

Stone, Lawrence and Jeanne F. Stone, An Open Elite? England 1540-1880, Oxford, 1984.

Stringer, K. J., Essays on the Nobility of Medieval Scotland, Edinburgh, 1985.

Strong, Roy and Marcus Binney and John Harris, The Destruction of the Country House 1875-1975, London, 1974.

Taylor, James, Great Historic Families of Scotland, Baltimore, 1995.

Thompson, F. M. L., “Desirable Properties”, Historical Research, 64, 1991.

Thompson, F. M. L., English Landed Society in the Nineteenth Century, London, 1971.

Thompson, F. M. L., "Life after Death: How Successful Nineteenth-Century Businessmen Disposed of Their Fortunes”, Economic History Review, sec. ser., 43, 1990, 40-61.

Thompson, H. L., "The Poyntz Family”, Transactions of the Bristol and Gloucestershire Archeological Society, 4, 1879-80, 73-85.

Thorold, Henry, Harland Walshaw, and Peter Burton, Lincolnshire Houses, Norwich, 1999. 
Turner, M. E., J. Beckett, B. Afton, Agricultural Rent in England, 1690-1914, Cambridge, 2004. Tyack, Geoffrey, Warwickshire Country Houses, Chichester, 1994.

Wagner, Anthony, English Genealogy, Oxford, 1972.

Ward, J. T. and R. G. Wilson, Land and Industry: The Landed Estates and the Industrial Revolution, Newton Abbot, 1971.

Warrand, Duncan, Hertfordshire Families, Victoria County History, London 1907, 243-51.

Wasson, Ellis, Aristocracy and the Modern World, Basingstoke, 2006.

Wasson, Ellis, Born to Rule: British Political Elites, Stroud, 2000.

Waterson, Edward and Peter Meadows, Lost Houses of the West Riding, York, 1998.

Wedgwood, Josiah, Staffordshire Parliamentary History, London, 1920-22, 3 vols.

Whiteley, William Henry, The Social Composition of the House of Commons, 1868-1885, unpublished Ph.D thesis, Cornell University, 1960, 2 volumes.

Wiener, Martin J., English Culture and the Decline of the Industrial Spirit 1850-1980, Cambridge, new ed., 2004.

Wightman, Andy, Who Owns Scotland, Edinburgh, 1996.

Williams, Glanmor, ed., Glamorgan County History, IV, Cardiff, 1974.

Williams, W. R., The Parliamentary History of the City of Oxford 1313-1899, Breknock, 1899.

Williams, W. R., The Parliamentary History of the Principality of Wales, 1541-1895, Brecknock, 1895.

Willson, F.M.G., A Strong Supporting Cast: the Shaw Lefevres 1789-1936, London, 1993.

Wilson, R. G., Gentlemen Merchants: the Merchant Community in Leeds, 1700-1830, Manchester, 1971.

Winter, C. W. R., The Manor Houses of the Isle of Wight, Stanbridge, 1984.

Wood, Florence and Kenneth, eds., A Lancashire Gentleman, The Letters and Journals of Richard Hodgkinson 1763-1847, Stroud, 1992.

Worsley, Giles, England's Lost Houses, London, 2011.

Wright, William Ball, The Ussher Memoirs, Dublin, 1889.

Wyndham, H. A., A Family History 1410-1688, Oxford, 1939.

Ziegler, Philip, The Sixth Great Power: A History of One of the Greatest of All Banking Families: The House of Barings 1762-1929, New York, 1988. 